Valerio Sorbello

UDC 327(450)

Cultore della materia in Storia

Original Scientific Paper

contemporanea

Received: 01.11.2016.

Università degli Studi di Trieste

Accepted: 20.12.2016.

Dipartimento di Scienze Politiche e Sociali

sorbello.valerio@gmail.com

\title{
THE SUEZ CRISIS: A NEW START FOR ITALIAN FOREIGN POLICY?
}

\begin{abstract}
In the mid-1950s, Italy was seeking greater political autonomy from the United States and the Atlantic Alliance with regard to the Mediterranean Sea and the Middle East. This foreign policy approach took the name of "Neo-Atlanticism," a term invented by Giuseppe Pella in 1957. Under this framework, Italy tried to extend its political, economic, and cultural influence in the Middle East, relying on good relations with the Arab countries and the fact that it had not operated as a colonial power. The Suez crisis in 1956 represented the turning point in Italian foreign policy: the Italian government sought to play an active role in the controversy, presenting itself as the most credible and reliable mediator and aiming to enhance its international profile. However, Italy's willingness to present itself as a medium power was not supported by a sufficiently strong economic, political, or military background. Moreover, internal rifts and personal rivalries within the ruling government party, the Christian Democracy, as well as growing discontent among Italy's Western partners, made Italy reconsider its position with regard to the Suez crisis.
\end{abstract}

In September 1955, Egypt and Czechoslovakia signed an agreement to supply weapons that shook the Western world, presenting it with further concerns regarding the apparent expansion of Soviet influence in the Middle East. Within this general framework, this paper will focus on Italy and its role during the Suez crisis. Since the beginning of the Fifties, the Italian government had attempted to enact 
a new foreign policy aimed at being more autonomous from the United States and within the Atlantic Alliance while opening new perspectives of economic, political, and cultural penetration in the Arab countries.

On the eve of the crisis in the Middle East, the Arab countries, on the one hand, looked towards Rome as the most suitable Western partner for explaining their point of view to NATO's members. Gamal Abdel Nasser, the president of Egypt, confirmed this belief: "Italy may convince the West that Egypt is a free country and that it is not subjected to any protectorate." ${ }^{\prime}$ On the other hand, both London and Washington had to acknowledge the esteem that the Arab countries had for Italy; this prevented the United States and a more reluctant Great Britain from opposing the proposal of the Italian Foreign Ministry to invite Nasser to Italy for a State visit, which was intended to be an attempt to "enhance the relations between Arab countries and the West." ${ }^{2}$

Nasser's visit required detailed preparation so that adverse reactions by Italy's Allies could be avoided. However, two opposite leanings emerged in Italian foreign policy. There was Alberto Folchi, Undersecretary of State of Foreign Affairs, a man close to the President of the Italian Republic Giovanni Gronchi, who pushed, along with others, for delivering the invitation to the Egyptian President at the earliest possible time. Others, like Gaetano Martino, the Italian Minister of Foreign Affairs, preferred a more casual approach that would steer clear of one of the most controversial figures of that time.

Awaiting the official investiture of Nasser as President of Egyptian Republic, which occurred in the summer of 1956, Palazzo $\mathrm{Chigi}^{3}$ decided to send an unofficial invitation to the Rais via the Italian ambassador to Egypt, Giovanni Fornari. While the discussions on Nasser's visit were in the heart of their debate, Gronchi leaked during a state visit in Paris the information of the visit of the Egyptian president

\footnotetext{
${ }^{1}$ Wulzer Paolo, Il Mediterraneo nei rapporti italo-britannici (1945-1958), Aracne, Roma, 2010, p. 220.

${ }^{2}$ Onelli Federica, Allalba del neoatlantismo. La politica egiziana dell'Italia 1951-1956, Franco Angeli, Milano, 2013, p. 90.

${ }^{3}$ Palazzo Chigi was the seat of the Italian Foreign Affairs Ministry from 1922 until 1961. Here the expression "Palazzo Chigi" is used as a metonym of the Italian Foreign Affairs Ministry.
} 
to the press. His intention was to "reaffirm to Italian and international public opinion the role of Italy as the leading partner in Western foreign policy in Middle East at a time when French strategies were intended to diminish it."4 Between mid-May and the beginning of July, the Italian government prepared the schedule of the State visit, which included a tour of the most important industrial centres of the Italian peninsula, in addition to political meetings. Unfortunately, the deterioration of the international situation forced the Italian authorities to postpone to a later date the travel of the Egyptian president.

In July 1956, the United States withdrew its funding proposal for the construction of the Aswan Dam across the Nile, a huge project that would have revolutionized the Egyptian production system, in retaliation for the arms deal between Egypt and Czechoslovakia. The news of the American withdrawal caught the Italian government by surprise. On July $25^{\text {th }}$, Martino wrote to John Foster Dulles expressing widespread criticism towards American behavior that could have compromised not only years of good relations with Egypt but also any expectation of keeping Nasser in the Western camp. On July $26^{\text {th }} 1956$, Nasser promulgated a bill that nationalised the Universal Suez Ship Canal Company, whose toll revenue "would have been used for the construction of the Aswan Dam, allowing Egypt to avoid the economic and political blackmail by the United States and the United Kingdom"s.

The Western reactions were immediate: the bill heavily affected the United Kingdom and France, which were directly involved in the management of the Canal Company, but these European States were mainly concerned about the wider political impact of this measure. London perceived the nationalisation as a part of the Nasserian policy aimed at the destruction of Western positions in Middle East. Paris was concerned by the repercussions of Egyptian strengthening in the Algerian War, because it would have galvanized the National Liberation Front. Washington, on their part, condemned the Egyptian unilateral action, but it did not address Nasser in the threatening way the two European partners did, considering that the latter two did not exclude resorting to the use of force.

\footnotetext{
${ }^{4} I v i$, p. 89.

${ }^{5}$ Pizzigallo Matteo, Cooperazione e relazioni internazionali. Studi e ricerche sulla politica estera italiana del secondo dopoguerra, Franco Angeli, Milano, 2008, p. 77.
} 
Italy, instead, took a wait-and-see position, "in an attempt to maintain the equilibrium between the two key elements of the Italian presence in the Mediterranean Sea and the Middle East." 6 The official statement of the Italian government arose from careful consideration over the legal and economic aspects of the controversy, yet it was also a compromise between the different camps of the Government:

"Il Governo italiano segue con molta attenzione la situazione che si è venuta a creare relativamente al Canale di Suez in seguito alla nazionalizzazione della Compagni del Canale emanata dal governo egiziano. Gli aspetti giuridici della questione riguardano anche la libertà, in atto internazionalmente garantita, delle comunicazioni tra il Mediterraneo ed il Mar Rosso, linea di transito che è vitale per l'Italia. Così stando le cose il governo italiano non può non esprimere la propria preoccupazione per eventuali danni che potrebbero derivare alleconomia italiana, alle Compagnie di navigazione, ai privati cittadini, nel caso in cui le condizioni nelle quali si è svolto sinora il traffico attraverso il canale di Suez venissero alterate."

Egypt welcomed the Italian verbal note and the Egyptian Minister of Foreign Affairs, Mahmoud Fawzi, "appreciated its friendly spirit."

In this way, Italy managed to distinguish its foreign policy from that of the United States, France, and United Kingdom. The three "great powers" had signed a tripartite statement ${ }^{9}$ in which they condemned

\footnotetext{
${ }^{6}$ Ibidem.

7 "The Italian Government is following very closely the situation that has arisen from the nationalisation of the Canal Company as decided by the Egyptian government. The legal aspects of the issue refer to the international granted freedom of communications between the Mediterranean and the Red Sea. This is a passage of utmost importance for Italy. Under the current circumstances, the Italian Government has to express its concerns in case of any damages to the Italian economy, to shipping companies, and to citizens, in the event that the conditions of navigation through the Suez Canal were to be found altered". Annuario di politica internazionale, 1956, p. 596.

${ }^{8}$ Onelli Federica, Allalba del neoatlantismo. La politica egiziana dell'Italia 1951-1956, p. 96.

${ }^{9}$ Tripartite Statement Issued at London, August 2, 1956, FRUS 1955-1957, vol. XVI, pp. 126-7.
} 
the nationalisation as "a threat to the freedom and security of the Canal as guaranteed by the Constantinople Convention of the Suez Canal of 1888." ${ }^{10}$ The last article of the statement provided for the convocation of an international conference of the largest users of the Canal to be held in London on August $16^{\text {th }}$.

The Italian diplomatic delegation attended the Conference in London with definite guidelines: "the strict request of international guarantees on the freedom of movement, on tariffs stability, and on the efficiency of the Canal's infrastructures; the maintenance of Western solidarity; strong opposition to any military option." ${ }^{11}$ These guidelines helped the Italian authorities to elaborate upon a plan to mediate the controversy, which should have been approved by Egypt. On the morning of August $9^{\text {th }}$, after an inner Cabinet meeting, Gronchi, Segni, Saragat, ${ }^{12}$ and Marino sent instruction to Ambassador Fornari to present the Egyptian Ministry of Foreign Affairs with the two-point solution that Italy planned to present in London: "1) adoption of a «International Statute of the Canal» which establishes the reciprocal rights and obligations of Egypt and the users of the Canal; 2) the setting up of an International Supervisory Committee mandated to guarantee the implementation of the Statute."13 The proposal was brought to the attention of Fawzi, who, thanking Italy "for the «undoubtedly friendly gesture»,"14 expressed his perplexity concerning the "International Supervisory Committee."

Martino landed in London on August $16^{\text {th }}$ and had three private meetings with the U.S. Secretary of State Dulles, the British Prime Minister Anthony Eden, and the French Minister of Foreign Affairs, Christian Pineau. None of them recognised the Italian position: Dulles confined the Italian proposal to that of a last resort; Eden and Pineau

\footnotetext{
${ }^{10}$ Ibidem.

${ }^{11}$ Wulzer Paolo, Il Mediterraneo nei rapporti italo-britannici (1945-1958), pp. 265-6.

${ }^{12}$ Antonio Segni was the President of the Council of Ministers of the Italian Republic from July 1955 to May 1957; Giuseppe Saragat was the Deputy President of the Council of Ministers of the Italian Republic from February 1954 to May 1957.

${ }^{13}$ Pizzigallo Matteo, Cooperazione e relazioni internazionali. Studi e ricerche sulla politica estera italiana del secondo dopoguerra, p. 85.

${ }^{14}$ Ivi, 87.
} 
rejected the conciliatory Italian point of view. Without going into the merits of the Conference, the Italian action did not bring any results. The Italian delegation was even accused of "not having supported with the necessary conviction the Italian plan"15 of President Gronchi, who never desisted from pressing Segni for adopting a more supportive stand of Egyptian needs.

In the meantime, a five-member commission ${ }^{16}$ chaired by the Prime Minister of Australia, Robert Menzies, was sent to Cairo in order to present the final draft of the Conference. Following the American proposal, the document provided for "the creation of «a system that guarantees the free use of the Suez Canal at any time and for all the States, without prejudice to Egyptian sovereignty and without any political influence of any State over the management of the Canal». Egypt will earn a «royalty» from the use of the Canal"17. Nasser - as expected - rejected the document.

While the Menzies mission was failing in Cairo, on August 26th, 1956, the Secretary of Christian Democracy, Amintore Fanfani, was travelling to the United States for a meeting with the Undersecretary of State for Political Affairs, Robert D. Murphy. Fanfani was one of the strongest advocates of "Neo-Atlanticism" and "friendship diplomacy" towards the Arab countries. He was emerging as a leader in the Italian political landscape precisely during the Suez Crisis thanks to his dynamism aimed at "ensuring that a course of action favourable to a peaceful mediation and to a distinction between ownership of the Canal and freedom of its navigation." This orientation directed Fanfani's approach during his visit to Washington. While talking with Murphy, Fanfani expressed his satisfaction for the evolution of the cooperation between Italy and the United States, especially regarding the Mediterranean Sea and the Middle East, where the United States should have "taken advantage of their primacy in the crisis management." 18

\footnotetext{
${ }^{15}$ Ivi, 97.

${ }^{16}$ The commission was composed by Australia, Ethiopia, Iran, Sweden and the United States.

${ }^{17}$ Calchi Novati Giampaolo, Il canale della discordia: Suez e la politica estera italiana, Quattro Venti, Urbino, 1998, p. 43.

${ }^{18}$ Memorandum of conversation, Department of State, Washington, August 27, 1956,
} 
Once Fanfani went back to Rome, he worked on opening "a channel for direct dialogue"19 with Nasser. In order to achieve this, the Secretary of the Christian Democracy entrusted his friend Giorgio La Pira, major of Firenze, to contact a former Minister closely linked to Nasser. On September $5^{\text {th }}$, La Pira met his contact at the Embassy of Egypt in Rome and asked him to see reason with the Rais to reach a peaceful deal "using as a basis the final draft of the Conference of London."20

In mid-September, a second conference was convened in London, but this time the states opposing the American proposal adopted in August were not invited. The conference concluded on September $21^{\text {st }}$ with the founding of the Suez Canal Users Association (SCUA) and the possibility of recourse to the United Nations.

Simultaneous to the closure of the International Conference on the Suez Canal, Fanfani succeeded in persuading Nasser, through the intercession of Enrico Mattei ${ }^{21}$, of the need to negotiate on certain terms: that an Egyptian and an American delegate had to be present and that the meeting had to be unofficial. Fanfani did not hesitate to inform Eisenhower of such openness, but the American president preferred not to conduct negotiations without keeping France and the United Kingdom informed. Thus, Fanfani's manoeuvres failed. However, the Italian government received Nasser's "warm thanks for the comprehensive and equitable endeavour during the second Conference of London." ${ }^{22}$ At the end of September, the controversy was referred to the UN Security Council that protracted the debate for more than one month. France, the United Kingdom, and Israel took advantage of this deadlock for covering the preparation of the attack against Egypt drawn up in Sevrès on October 26th.

FRUS, 1955-1957, vol. XXVII, pp. 375-8.

${ }_{19}$ Pizzigallo Matteo, Cooperazione e relazioni internazionali. Studi e ricerche sulla politica estera italiana del secondo dopoguerra, p. 102.

${ }^{20}$ Ibidem.

${ }^{21}$ Enrico Mattei was the President of Ente Nazionale Idrocarburi (ENI), Italy's national oil company.

${ }^{22}$ Pizzigallo Matteo, Cooperazione e relazioni internazionali. Studi e ricerche sulla politica estera italiana del secondo dopoguerra, p. 103. 
On October $29^{\text {th }}$, Israel attacked Egypt in Sinai. On the following day, France and the United Kingdom issued a twelve-hour ultimatum to the two belligerents demanding a cease-fire and withdrawal of the troops to 10 miles west and east of the Canal in twelve hours. As expected, Egypt rejected the withdrawal of its army from the Egyptian territory. Once the ultimatum expired, France and the United Kingdom launched the "Musketeer" operated that provided for the bombing of the Canal zone and the landing of paratroopers in the area in order to take control of the Canal. On November $2^{\text {nd }}$, Egypt scuttled some of its vessels at the Suez Canal, blocking it. In the meantime, British and French troops occupied three strategic areas: Port Said, Ismailia, and Suez.

In New York, the UN General Assembly gathered in an emergency plenary session and promptly adopted three resolutions: Resolution 997 (ES-I) of November 2, 1956, demanding a cease-fire, the withdrawal of Israeli forces behind the Armistice demarcation line of 1948, abstaining from any action that could compromise the entry into force of the Resolution, and the reopening and securing of the Suez Canal, ${ }^{23}$ Resolution 998 (ES-I) of November 4, 1956, demanding authorisation for the creation of an intervention force under UN auspices that would supervise the implementation of the Resolution of November $2^{\text {nd } 24}$ Resolution 999 (ES-I), of November 4, 1956, reminding all the parties to implement the first Resolution..$^{25}$

The United States was kept in the dark about the military intervention of its European allies and strongly condemned the FrancoBritish action. This opened the first major crisis within NATO, made even worse by the fact that the action prevented the United States from morally condemning the Soviet invasion of Hungary launched on November 4, 1956.

The Italian reaction was surprisingly not so harsh. The Minister of Foreign Affairs Martino wired the Permanent Representative of

\footnotetext{
${ }^{23}$ United Nations General Assembly (UNGA), Resolution (Res.) 997 (ES-I), November $2^{\text {nd }} 1956$.

${ }^{24}$ UNGA, Res. 998 (ES-I), November $4^{\text {th }} 1956$.

${ }^{25}$ UNGA, Res. 999 (ES-I), November $4^{\text {th }} 1956$.
} 
Italy to the United Nations in New York, Leonardo Vitetti, the official position of the Italian government:

"V.E. è pregata di voler allinearsi sia per quanto concerne suo intervento alla riunione straordinaria Assemblea sia per votazione all'atteggiamento americano. Tenendo presente però che la solidarietà occidentale e necessità non turbare eccessivamente nostre relazioni con governi inglese e francese è e rimane fondamento di politica estera italiana, prego V.E. voler contenere termini moderati redazione testo eventuale mozione censura e formulare intervento in maniera comprensiva per gli interessi anglo-francesi." ${ }^{26}$

Although Italy had a significant opportunity to distance itself from the Franco-British position, aligning itself with the American one and proposing a more determinate presence in the Mediterranean Sea and in the Middle East, as Gronchi, Fanfani, and a large part of Palazzo Chigi requested, (However,) it was also true what the Italian Ambassador in London, Vittorio Zoppi, pointed out to Martino:

"Qualche volta potremmo essere tentati di seguire l'esempio degli Stati Uniti, i quali, come potenza mondiale e data la varietà e complessità dei loro interessi, si permettono di deludere i loro partners europei [...] [Ma] ciò che è permesso ad una potenza come gli Stati Uniti non è concesso ad altri paesi. Questi anzi possono trovarsi esposti a attirare su di sé quei rancori che $[\ldots]$ non possono riversarsi sull'America." ${ }^{27}$

\footnotetext{
26 "H.E. is requested to align himself with the American behaviour both with regard to your speech at the General Assembly extraordinary session and with regard to the vote. Bearing in mind that Western solidarity and the need to not upset excessively our relations with the British and the French governments are and have to be the bedrock of our foreign policy, I ask H.E. to use moderate terms while drafting a motion of censure and to formulate your speech in a sympathetic way towards Franco-British interests."Onelli Federica, Allalba del neoatlantismo. La politica egiziana dell'Italia 1951-1956, p. 121.

27 "Sometimes we may let ourselves be tempted to follow in the footsteps of the United States, who is allowed to disappoint its allies since it is a great power and given the variety and complexity of its interests [...]. [However] what is allowed to the United States is not permitted to other States. The latter, on the contrary, may be subject to those rancours that $[\ldots]$ could not be expressed in relations to America”. Brogi Alessandro,
} 
The "temptation" Zoppi was talking about could have cost dearly to Italy. The risk of the consolidation of the "entente" between France and the United Kingdom and the risk of the stiffening of the Italian position on the Suez issue would have compromised the relaunch of the European integration process. Bearing this in mind, it is possible to understand the Italian action during the Suez crisis: (1) to improve relations with European powers rather than making them worse; (2) to take the opportunity to bolster the Atlantic Alliance rather than taking advantage of the situation to enhance national prestige. Thus, on the one hand, Martino condemned the use of force and the delegitimization of the UN work, while on the other hand he tried to see the Franco-British decision from a positive perspective without paying attention to those who raised a claim of malice aforethought. Following this route, Italy abstained from voting on Resolution 1120 (XI) of November 24, 1956 that was promoted by the United States and that demanded a quicker phase-out of the Franco-British forces from the Suez Canal ${ }^{28}$.

The British Ambassador in Rome, Ashley Clarke, clearly stressed in his reports this tendency of Italian diplomacy. According to him, "Italy, despite its Mediterranean ambitions and its privileged relationship with the majority of the Arab countries, would not be able to be autonomous from the Western sphere and to strengthen its position at the expense of its European allies."29 The Foreign Office shared Clarke's analysis, and Anthony Eden, surprised that Italy had been so close to the British position, expressed his thanks to the Italian Prime Minister Segni "for taking into consideration the [...] British arguments." ${ }^{30}$

The position of Segni drew criticism from the President of the Italian Republic, who feared a deterioration of relations with the Arab countries. In particular, Gronchi was concerned about a confidential note sent to him by the Egyptian Ambassador in Rome in which was expressed disappointment for "Italy's lenient attitude towards Paris and

L'Italia e l'egemoniaamericananelMediterraneo, p. 231.

${ }^{28}$ UNGA, Res. 1120 (XI), 24 November 1956.

${ }^{29}$ WUlzer Paolo, Il Mediterraneo nei rapporti italo-britannici (1945-1958), p. 283.

${ }^{30}$ Ivi, p. 289. 
London."31 Criticism of the softer line adopted by Segni and Martino also came from the United States: during the NATO meeting in December 1956, the US Secretary of State stressed that during the Suez crisis "the "politics of principle» should have prevailed the «politics of friendship»,"32 not the contrary.

Meanwhile, after Egyptian approval in mid-November, the United Nations Emergency Force (UNEF) was deployed in the area of the Suez Canal and its mission was to maintain and supervise the end of the hostilities. The withdrawal operation of the French, British, and Israeli forces ended in March 1957, when the last Israeli troops left Sharm El Sheikh and Gaza.

The Suez conflict had very significant implications on the international level. The outcome of the war determined the decline of the last two colonial powers in Europe, France and the United Kingdom, and it reduced their capacity of projection in the Middle East. It sanctioned the supremacy of the United States' hegemony on the Mediterranean Sea and the Middle East; it moved the center of gravity of the Cold War and of the US-Soviet rivalry to the Middle East, a neutral zone until then. Finally, the war revivified the Arab rancour against Israel, contributing to the chronic instability of the area.

In Italy, the Suez crisis made explicit the conflict within the policy-makers on how to enact foreign policy and it risked becoming "the reason for a great rift within the democratic coalition" ${ }^{33}$ for the first time since 1947. On the one hand, those like Martino and Segni sought total loyalty to NATO and to the European integration process; on the other hand, those others like Gronchi, Pella, Fanfani, and Mattei strove for enhancing Italy's "peculiarity" and raising the Italian international profile. Internal rifts and personal rivalries, rather than the constraints derived from the Atlantic Alliance or the direct pressure from its allies, prevented Italy from constructing an autonomous, coherent, and comprehensive foreign policy towards the Middle East.

\footnotetext{
${ }^{31}$ OnELli Federica, Allalba del neoatlantismo. La politica egiziana dell'Italia 1951-1956, p. 123.

${ }^{32}$ Ibidem.

${ }^{33}$ Wollenborg L. J., Stars, Stripes and Italian Tricolor: the United States and Italy 19461989, Praeger Publishers, New York, 1990, p. 60.
} 


\section{$\underline{\text { BIBLIOGRAPHY }}$}

CACACE Paolo, Venti anni di politica estera italiana (1943-1963), Bonacci editore, Roma, 1986

Calchi Novati Gian Paolo, Il canale della discordia: Suez e la politica estera italiana, Quattro

Venti, Urbino, 1998

Calchi Novati Gian Paolo, Mediterraneo e questione araba nella politica estera dell'Italia, in AA. VV. "Storia dell'Italia repubblicana", vol. 2, tomo I, Einaudi, Torino, 1995

De Leonardis Massimo (a cura di), Il Mediterraneo nella politica estera italiana del dopoguerra, Bologna, 2003

Di Nolfo Ennio, Rainero Romain H., Vigezzi Bruno (a cura di), L'Italia e la politica di potenza in Europa (1950-1960), Marzorati, Settimo Milanese, 1992

FERRARIS Luigi Vittorio (a cura di), Manuale di politica estera italiana 1947-1993, Editori Laterza, Roma-Bari, 1996

Istituto per gli Studi di Politica Internazionale, Annuario di politica internazionale, 1956, Dedalo, Bari, 1957

Mammarella Giuseppe, Cacace Paolo, La politica estera dell'Italia. Dallo Stato unitario ai giorni nostri, Editori Laterza, Roma-Bari, 2012 Onelli Federica, All'alba del neoatlantismo. La politica egiziana dell'Italia 1951-1956, Franco Angeli, Milano, 2013

Pizzigallo Matteo, Cooperazione e relazioni internazionali. Studi e ricerche sulla politica estera italiana del secondo dopoguerra, Franco Angeli, Milano, 2008

Sabbatucci Giovanni, Vidotto Vittorio, Storia d'Italia. Vol. 5 La Repubblica, Editori Laterza, Roma-Bari, 2004

United States Department of State, The Foreign Relations of the United States, 1955-1957. Western Europe and Canada, vol. XXVII, P. John Glennon (Editor), U.S. Government Printing Office, Washington D.C., 1992

VARSORI Antonio (a cura di), La politica estera italiana nel secondo dopoguerra 1943-1957, LED, Milano, 1993

VARSORI Antonio, L'Italia nelle relazioni internazionali dal 1943 al 1992, Laterza, Roma, 1998 
Wollenborg Leo J., Stelle, strisce e tricolore. Trentanni di vicende politiche fra Roma e Washington, Mondadori, Milano, 1983 Wulzer Paolo, Il Mediterraneo nei rapporti italo-britannici (1945-1958), Aracne, Roma, 2010 